\title{
Gestational Day-Dependent Expression of Interleukin-10 and Tumor Necrosis Factor-alpha in Porphyromonas gingivalis-infected Pregnant Rats
}

\author{
Banun Kusumawardani ${ }^{1}$, Marsetyawan HNE. Soesatyo ${ }^{2}$, Djaswadi Dasuki ${ }^{3}$, Widya \\ Asmara $^{4}$ \\ ${ }^{1}$ Department of Biomedic, Faculty of Dentistry, University of Jember, Jember 68121, Indonesia \\ ${ }^{2}$ Department of Histology and Cell Biology, Faculty of Medicine, Universitas Gadjah Mada, Yogyakarta \\ 55281, Indonesia \\ ${ }^{3}$ Department of Obstetric and Gynecology, Faculty of Medicine, Universitas Gadjah Mada, Yogyakarta \\ 55281, Indonesia \\ ${ }^{4}$ Department of Microbiology, Faculty of Veterinary Medicine, Universitas Gadjah Mada, Yogyakarta \\ 55281, Indonesia \\ Correspondencee-mail to:kusumawardani_banun@yahoo.co.id
}

\begin{abstract}
Fetal growth restriction remains a major cause of neonatal morbidity and mortality. Porphyromonas gingivalis can induce placental inflammatory response resulting in fetal growth restriction. Objective: This study aimed to evaluate the potential utility of the pro-inflammatory cytokine TNF- $\alpha$ and anti-inflammatory cytokine IL-10 in rat placental tissues to understand whether these events were causally related. Methods: Female rats were infected with live-Porphyromonas gingivalis at concentration of $2 \times 10^{9}$ cells $/ \mathrm{ml}$ into subgingival sulcus area of the maxillary first molar before and/or during pregnancy. They were sacrificed on gestational day (GD)-14 and GD20. The expression of TNF- $\alpha$ and IL-10 in macrophages and trophoblast cells were detected by immunohistochemistry. Results: A higher expression of TNF- $\alpha$ was found in spongiotrophoblast of the Pg-BD group on GD14 (6.30 \pm 1.16 ), and in trophoblastic giant cells of Pg-D group on GD20 (5.50 \pm 1.35$)$. Furthermore, a higher expression of IL-10 was found in trophoblastic giant cells of the Pg-BD group on GD14 (4.50 \pm 1.51$)$ and in syncytiotrophoblasts of Pg-BD group on GD20 (8.70 \pm 2.67$)$. Conclusion: The expression of TNF- $\alpha$ on GD14 and GD20 were accompanied by increased expression of IL-10. The placental pathologic conditions induced by Porphyromonas gingivalis can be inhibited by elevated expression of IL-10 in macrophages and trophoblast cells.
\end{abstract}

\begin{abstract}
ABSTRAK
Ekspresi Interleukin-10 dan Tumor Necrosis-alpha terkait hari kehamilan pada tikus yang terinfeksi Porphyromonas gingivalis. Restriksi pertumbuhan janin masih menjadi penyebab utama morbiditas dan mortalitas neonatal. Porphyromonas gingivalis dapat menginduksi respon inflamasi plasenta yang mengakibatkan restriksi pertumbuhan janin. Tujuan: Penelitian ini bertujuan untuk mengevaluasi potensi sitokin pro-inflamasi TNF- $\alpha$ dan sitokin anti-inflamasi IL-10 pada jaringan plasenta tikus untuk memahami peristiwa yang saling berkaitan dengan kasus restriksi pertumbuhan janin. Metode: Tikus betina diinfeksi dengan live-Porphyromonas gingivalis pada konsentrasi $2 \times 10^{9} \mathrm{sel} / \mathrm{ml}$ di area sulkus subgingiva molar pertama rahang atas sebelum dan/atau selama kehamilan. Tikus tersebut dikorbankan pada hari kehamilan (GD)-14 dan GD20. Ekspresi TNF- $\alpha$ dan IL-10 pada makrofag dan sel-sel trofoblas dideteksi secara imunohistokimia. Hasil: Ekspresi TNF- $\alpha$ lebih banyak ditemukan pada spongiotrofoblas kelompok Pg-BD pada GD14 $(6,30 \pm 1,16)$ dan sel-sel raksasa trofoblastik kelompok Pg-D pada GD20 (5,50 $\pm 1,35)$. Selain itu, ekspresi IL-10 lebih banyak ditemukan pada sel-sel raksasa trofoblastik kelompok Pg-BD pada GD14 (4,50 \pm 1,51), dan sinsitiotrofoblas kelompok Pg-BD pada GD20 (8.70 \pm 2.67$)$. Simpulan: Ekspresi TNF- $\alpha$ pada GD14 dan GD20 disertai oleh peningkatan ekspresi IL-10. Kondisi patologis plasenta yang diinduksi Porphyromonas gingivalis dapat dihambat oleh peningkatan ekspresi IL-10 pada makrofag dan sel-sel trofoblas.
\end{abstract}

Key words: interleukin-10, periodontal disease, placenta, pregnancy, tumor necrosis factor-alpha 


\section{INTRODUCTION}

Fetal growth restriction remains a major cause of neonatal morbidity and mortality. However, mechanisms underlying the etiology of fetal growth restriction and methods to reverse impaired fetal growth remain poorly understood. The maternal immune response is a key determinant of the success or failure of pregnancy, and disruption of the necessary adaptations to accommodate the conceptus is implicated in unexplained recurrent miscarriage in women. 1 The maternal immune response is principally regulated by an array of cytokines acting in complex networks to orchestrate the changes in leukocyte populations required to protect the conceptus from fetal immune rejection and to facilitate the tissue remodeling processes necessary for adequate placental development. ${ }^{2-4}$ Inflammatory processes induced by host defense to infection or by immune disorders independent of infection are a major challenge to successful pregnancy. 1,5

Our previous studies showed that Porphyromonas gingivalis as the primary etology of periodontal disease can adversely affect on pregnancy. ${ }^{6}$ The subgingival Porphyromonas gingivalis infection in pregnant rats can increase the activation of Toll-like receptor (TLR)-2 and TLR4 on macrophages and trophoblast cells resulting in fetal growth restriction. ${ }^{7,8}$ TLR ligation can result in activation of nuclear factor- $\kappa \mathrm{B}(\mathrm{NF}-\kappa \mathrm{B})$ and production of cytokines. ${ }^{9}$ Several cytokines have been involved in the balance of the immune system and can affect the growth of the placenta and fetus. Abberant levels of tumor necrosis factor-alpha (TNF- $\alpha$ ) are associated with recurrent spontaneous abortion, preeclampsia, preterm labor and intrauterine growth restriction. ${ }^{10}$

The modulatory balance of pro-inflammatory and antiinflammatory cytokines in pregnancy directly depends on the immunosuppressive action of interleukin (IL)$10 .{ }^{11} \mathrm{IL}-10$ plays a fundamental role among the active mechanisms which maintain immunologic modulation in pregnancy. ${ }^{12,13}$ From implantation until the end of a term pregnancy, the interaction between pro-inflammatory and anti-inflammatory cytokines is fundamental to promote normal pregnancy outcomes. Recent study of healthy pregnancy showed a global reduction of proinflammatory cytokines, such as TNF- $\alpha$, IL- $1 \beta$, and IL-6, and an increase of contra-regulatory cytokines, such as IL-10. This interaction reinforces the role of immune modulation in the maintenance and development of normal pregnancy. ${ }^{14}$

Both rat and human have haemo-chorial placenta, in which fetal trophoblast cells are dampened by maternal blood. ${ }^{15}$ On GD14, rat placenta is mature and composed of three layers, namely labyrinth, spongiotrophoblast and maternal decidua. Trophoblast and fetal blood vessels arrange the labyrinth of extensively branched villi, and will be larger and more branched extensively until the time of delivery on GD20. ${ }^{16}$ In the present study, we established an animal model of experimentally maternal periodontal disease, and evaluated the potential utility of the pro-inflammatory cytokine TNF- $\alpha$ and antiinflammatory cytokine IL-10 in rat placental tissues to understand whether these events were causally related.

\section{METHODS}

All procedures were approved by the Ethics Committee, Faculty of Medicine, Universitas Gadjah Mada, Yogyakarta-Indonesia. This study had taken female Sprague-Dawley rats, adult, 2 months, 150-250 g and primiparous. The rats were maintained on the controlled and standardized conditions. The subjects of study were consisted of two blocks, they were sacrificed on gestational day (GD)-14 and GD20. Each block of gestational day was subdivided into four groups, which consisted of the control group, no Porphyromonas gingivalis infection; the Pg-BD group, an infection of Porphyromonas gingivalis before and during pregnancy; the Pg-B group, an infection of Porphyromonas gingivalis before pregnancy; and the Pg-D group, an infection of Porphyromonas gingivalis during pregnancy. Each group consisted of five pregnant rats.

Before injecting Porphyromonas gingivalis, all female rats were given antibiotic to depress the "natural" resident flora, rats received in their water a daily dose of kanamycin $(20 \mathrm{mg})$ and ampicillin $(20 \mathrm{mg})$ for 4 days. Induction of experimental periodontitis was performed by injection of $0.05 \mathrm{ml}$ live-Porphyromonas gingivalis ATCC 33277 (MediMark, France) with a concentration of $2 \times 10^{9}$ cells $/ \mathrm{ml}$ that was dissolved in saline into the distopalatal and distobuccal gingival sulcus area of maxillary first molar. Injection was repeated every 3 days for 30 days. For infection after pregnancy, it was also performed by a repeated injection every 3 days for 19 days. Control group rats were injected saline $0.05 \mathrm{ml}$ as the treatment schedule of the treated group rats. Then, the female rats were mated with the same strain of male rat overnight ratio $2: 1$. The next morning, female rats were removed from the cages and examined the vaginal plug. If the vaginal plug was found, the day was recorded as GD1.

Furthermore, the placental immunohistochemically was undertaken to determine the expression of TNF- $\alpha$ and IL-10. Samples were incubated overnight at $4^{\circ} \mathrm{C}$ with primary antibody, rabbit polyclonal antibody anti-TNF- $\alpha$ dilution 1:1000 (Abbiotec, San Diego, CA, 1:10001:2000) and anti-IL-10 dilution 1:400 (Abbiotec, San Diego, CA, 1:200-1:500), whereas negative control was incubated with secondary antibody as a substitute for the primary antibody. TNF- $\alpha$ and IL-10 were expressed in the cytoplasm and/or nucleus. Data were presented as mean number of cells expressing TNF- $\alpha$ and IL-10 in each type of cell. These specimens were evaluated in macrophages of labyrinth zone (LM), junctional zone (SM) and decidua zone (DM), as well as syncytiotrophoblast 
(LS), spongitrophoblast (ST) and trophoblastic giant cell (DG), and were examined at X400 magnification.

One-way analysis of variance (ANOVA) with post hoc test was performed to compare the TNF- $\alpha$ and IL-10 expression in macrophages and trophoblast cells of the control and maternal periodontal infection groups. Value of significance was determined as $p<0.05$. Numerical data were presented in mean \pm standard deviation.

\section{RESULTS}

Tumor necrosis factor-alpha and IL-10 were expressed in the cytoplasm and/or nucleus of the syncytiotrophoblast, spongiotrophoblast, macrophages and trophoblastic giant cell (Figure 1). TNF- $\alpha$ expression in the placenta of the control, Pg-BD, Pg-B and $\mathrm{Pg}-\mathrm{D}$ groups were significantly different $(p<0.05)$ in the syncytiotrophoblast, trophoblastic giant cells and spongiotrophoblast on GD14 (Figure 2). A higher expression of TNF- $\alpha$ was found in spongiotrophoblast of the Pg-BD group on GD14 (6.30 \pm 1.16$)$. However, the expression of TNF- $\alpha$ in the placenta of the control, $\mathrm{Pg}-\mathrm{BD}, \mathrm{Pg}-\mathrm{B}$ and $\mathrm{Pg}-\mathrm{D}$ groups were only significantly different $(p<0.05)$ in the syncytiotrophoblast and trophoblastic giant cell on GD20 (Figure 3). A higher expression of TNF- $\alpha$ was found in trophoblastic giant cells of Pg-D group on GD20 (5.50 \pm 1.35$)$.

Furthermore, IL-10 expressions of the control, Pg-BD, Pg-B and Pg-D groups were significantly different $(p<0.05)$ in macrophages of decidual zone and trophoblastic giant cells on GD14, while IL-10 expressions of the control, Pg-BD, Pg-B and Pg-D groups on GD20 were significantly different $(p<0.05)$ in macrophages of junctional zone and syncytiotrophoblasts (Fig. 4 and 5). Both GD14 and GD20, the Pg-BD, Pg-B and Pg-D groups had a higher IL-10 expression than control group (Table 2). A higher expression of IL-10 was found in trophoblastic

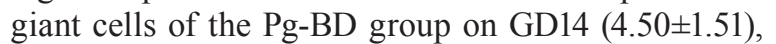
and in syncytiotrophoblasts of Pg-BD group on GD20 (8.70 \pm 2.67$)$.

\section{DISCUSSION}

A rat fetus is maintained in individual amniotic sacs in two uterine horn. Each fetus has its own placenta, which is similar to a disc-shaped human placenta. ${ }^{17}$ Both rat and human have haemo-chorial placenta, in which fetal trophoblast cells are dampened by maternal blood. ${ }^{15}$ On GD14, rat placenta is mature and composed of three layers, namely labyrinth, spongiotrophoblast and maternal decidua. Trophoblast and fetal blood vessels arrange the labyrinth of extensively branched villi, and will be larger and more branched extensively until the time of delivery on GD20. ${ }^{16}$ Functional differences between rat and human placenta may reflect different gestation period, and altricial delivery in rats. Rat pregnancy only lasts for three weeks, while human and other primates have a relatively long gestation period and usually give birth to a single offspring. ${ }^{18}$

On GD14 and GD20, TNF- $\alpha$ was not only expressed in the infected group, but also in the control group. Its role in the control group was very speculative, but was thought to be involved in the early growth of the fetus. These data indicated the complexity of TNF- $\alpha$ regulation at the fetomaternal interface. In the aspect of maternal, TNF- $\alpha$ had been identified in the macrophages of decidual zone. Trophoblasts migrated into the decidua and spiral arteries stroma to replaced the maternal endothelial cells. This process was thought to be associated with enlarged diameter of the blood vessels resulting in increased blood supply and oxygen to the placenta and fetus. ${ }^{10} \mathrm{TNF}-\alpha$ was produced to regulate trophoblast proliferation and differentiation, cell adhesion, tissue remodeling, villous trophoblast apoptosis and trophoblast hormone production..$^{19}$ TNF- $\alpha$ might be important during the preimplantation period, for decidual lymphangiogenesis, to promote labour at term, as well as to limit the extent of trophoblast invasiveness. ${ }^{10}$ This suggested that the lower expression of TNF- $\alpha$ was beneficial to the pregnancy, while increased expression was very detrimental. Therefore, early implantation and a successful pregnancy depended on the tight regulation of TNF- $\alpha$ expression in placental tissue.

The balance between pro-inflammatory and antiinflammatory cytokines is essential for placental development. Interleukin-10 has been implicated as a major modulator of anti-inflammatory cytokine cascade that was initiated by the synthesis of intrauterine infection. IL-10 was identified as a counterbalance synthesis of pro-inflammatory cytokines. ${ }^{20}$ Studies in mice and human suggested that IL-10 are involved in the regulation of inflammatory processes during pregnancy. IL-10 is expressed abundantly in decidual and placental tissues of mice and human..$^{21,22}$

In this study, IL-10 was widely expressed on GD14 and GD20. IL-10 was allegedly involved in many important events, including the placental formation and fetal growth. In early pregnancy, IL-10 has a protective effect on fetoplacental unit because it can inhibit the secretion of pro-inflammatory cytokines such as IL- 6, TNF- $\alpha$ and IFN- $\gamma$, and IL-10 together with IL-4 and IL-13 can also modulate trophoblast invasion. ${ }^{23,24}$ It proposed that the synthesis of IL-10 is a key determinant of vulnerability or resistance to fetal pathologic conditions induced by Porphyromonas gingivalis. Thus, the protective effect of IL-10 in the placenta will be deployed through inhibitory effects on macrophages and trophoblasts resulting in a decrease in synergistic activity mediated by TNF- $\alpha$. These conditions extend the understanding of the role of anti-inflammatory IL-10 in the placenta 
A

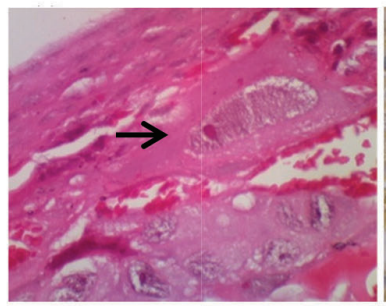

$\mathrm{D}$

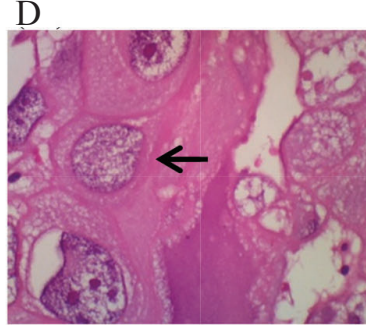

$\mathrm{B}$

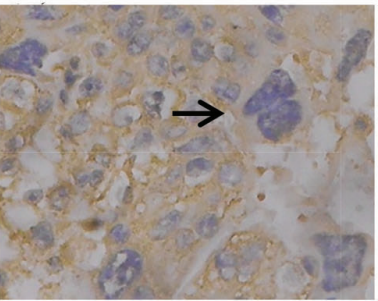

$\mathrm{E}$

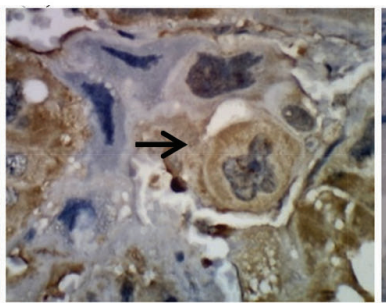

$\mathrm{C}$

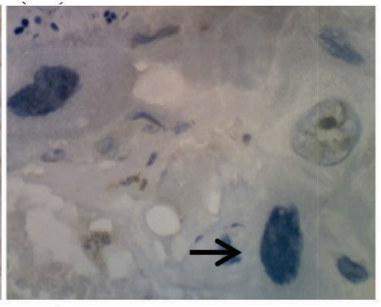

F

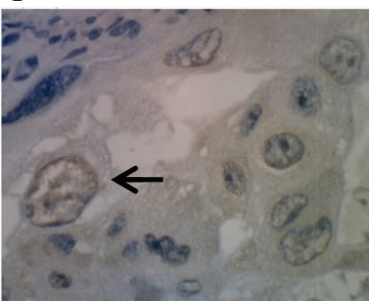

Figure 1. Decidual zone of the control group (A) and Pg-D (D) on GD20. Trophoblastic giant cells $(\rightarrow)$ located between the junctional zone and decidual zone. Trophoblastic giant cells were also found around the lumen of spiral arteries in the maternal decidua which highly close to the junctional zone. TNF- $\alpha$ expression of the placental Pg-D group (E) was very strongly expressed in the cytoplasm and/or nucleus of the trophoblastic giant cells than control group (B). IL-10 expression of the placental Pg-D group (F) was quite strongly expressed in the cytoplasm and nucleus of the trophoblastic giant cells than control group (C). Magnification 400x.

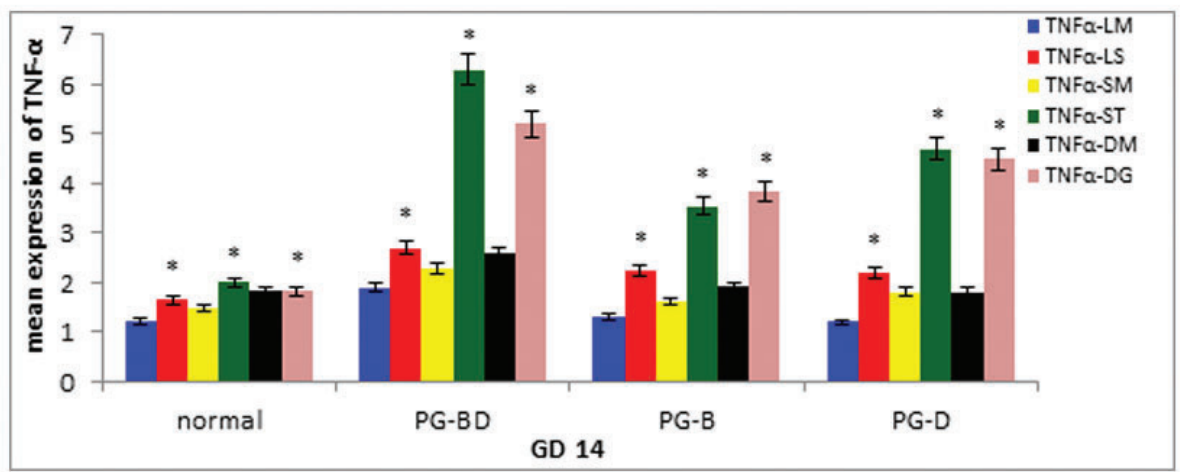

Figure 2. TNF- $\alpha$ expression in macrophages, syncytiotrophoblast, spongiotrophoblast, and trophoblastic giant cell in the 3 region of the placenta. Data were presented in the mean expression of TNF- $\alpha \pm$ SEM and compared by ANOVA $(* p<0.05)$ based on the maternal group of periodontal infection on GD 14. These specimens were evaluated in macrophages of labyrinth zone (LM), junctional zone (SM) and decidua zone (DM), as well as syncytiotrophoblast (LS), spongitrophoblast (ST) and trophoblastic giant cell (DG).

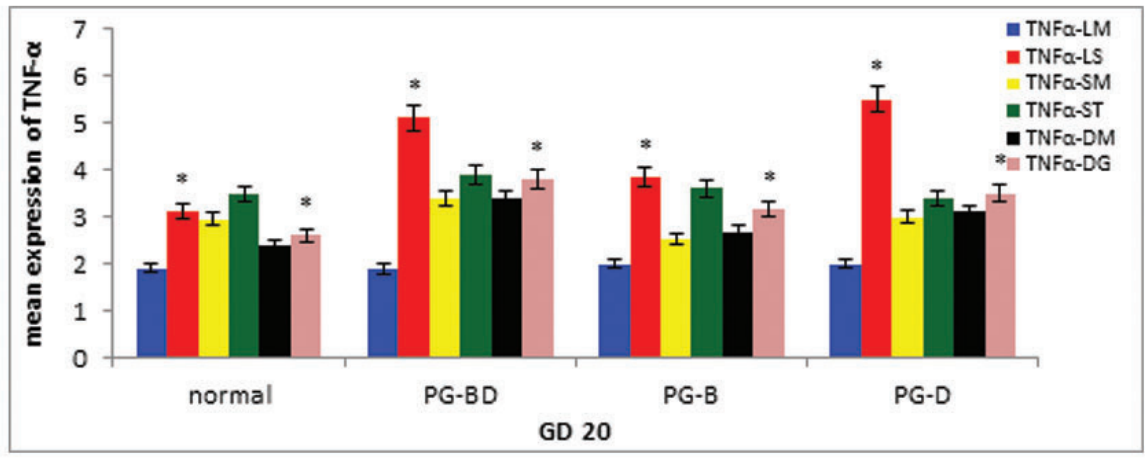

Figure 3. TNF- $\alpha$ expression in macrophages, syncytiotrophoblast, spongiotrophoblast, and trophoblastic giant cell in the 3 region of the placenta. Data were presented in the mean expression of TNF- $\alpha \pm$ SEM and compared by ANOVA $(* p<0.05)$ based on the maternal group of periodontal infection on GD 20. These specimens were evaluated in macrophages of labyrinth zone (LM), junctional zone (SM) and decidua zone (DM), as well as syncytiotrophoblast (LS), spongitrophoblast (ST) and trophoblastic giant cell (DG). 


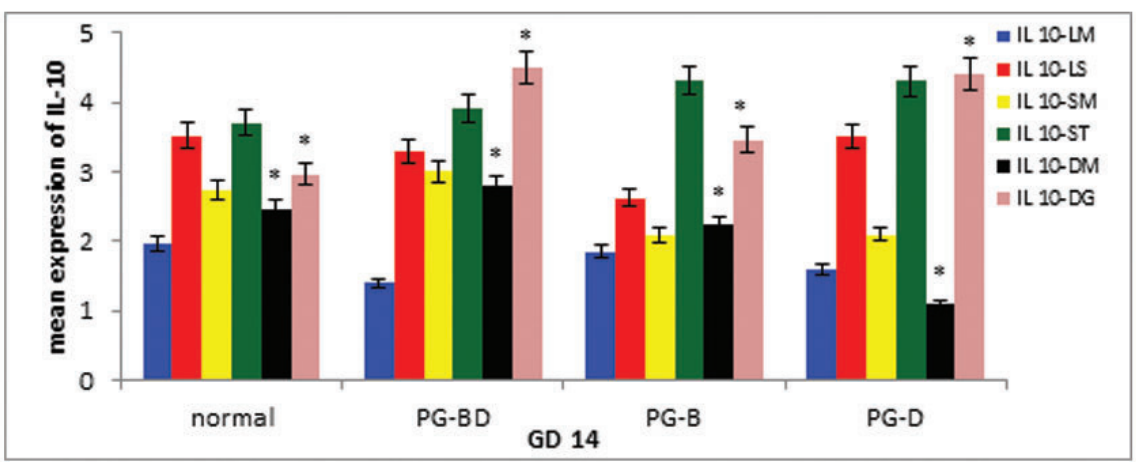

Figure 4. IL-10 expression in macrophages, syncytiotrophoblast, spongiotrophoblast, and trophoblastic giant cell in the 3 region of the placenta. Data were presented in the mean expression of IL-10 \pm SEM and compared by ANOVA $(* p<0.05)$ based on the maternal group of periodontal infection on GD 14. These specimens were evaluated in macrophages of labyrinth zone (LM), junctional zone (SM) and decidua zone (DM), as well as syncytiotrophoblast (LS), spongitrophoblast (ST) and trophoblastic giant cell (DG).

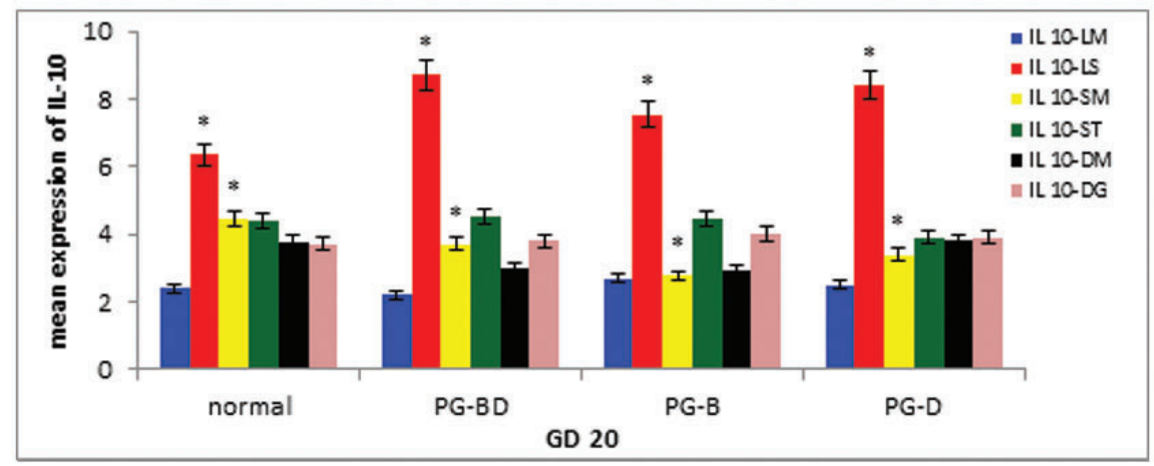

Figure 5. IL-10 expression in macrophages, syncytiotrophoblast, spongiotrophoblast, and trophoblastic giant cell in the 3 region of the placenta. Data were presented in the mean expression of IL-10 \pm SEM and compared by ANOVA $(* p<0.05)$ based on the maternal group of periodontal infection on GD 20. These specimens were evaluated in macrophages of labyrinth zone (LM), junctional zone (SM) and decidua zone (DM), as well as syncytiotrophoblast (LS), spongitrophoblast (ST) and trophoblastic giant cell (DG).

by demonstrating the role of governing the cytokine network which not only regulate macrophages but also regulate trophoblast cells.

\section{CONCLUSION}

It can be concluded that the expressions of TNF- $\alpha$ and IL-10 were affected by Porphyromonas gingivalis infection on maternal periodontal tissues. The expressions of TNF- $\alpha$ on GD14 and GD20 were accompanied by increased expression of IL- 10 . Our results suggested that the placental pathologic conditions induced by Porphyromonas gingivalis can be inhibited by elevated expression of IL-10 in macrophages and trophoblast cells. IL-10 may play a dual role in the auto-regulation and stimulation of pro-inflammatory cytokines in the microenvironment of the placenta.

\section{ACKNOWLEDGMENT}

We would like to thank Dr. Sitarina Widyarini, Dr. Tri Wibawa, Dr. Totok Utoro and Dr. Indwiani Astuti, and Prof. Al. Supartinah, each of whom has made invaluable contributions to our work. Their efforts, collaborations, insights, and discussions are greatly appreciated. This study was supported by grant no. 481/ SP2H/PP/DP2M/VI/2010 from Directorate General of Higher Education, Ministry of National Education - Indonesia.

\section{REFERENCES}

1. Laird SM, Tuckerman EM, Cork BA, Linjawi S, Blakemore AI, Li TC. A review of immune cells and molecules in women with recurrent miscarriage. Hum Reprod Update. 2003;9:163-74. 
2. Thellin O, Coumans B, Zorzi W, Igout A, Heinen E Tolerance to the foeto-placental 'graft': ten ways to support a child for nine months. Curr Opin Immunol. 2000;12:731-7.

3. Trowsdale J, Betz AG. Mother's little helpers: mechanisms of maternalfetal tolerance. Nat Immunol. 2006;7:241-6.

4. Croy BA, Chantakru S, Esadeg S, Ashkar AA, Wei Q. Decidual natural killer cells: key regulators of placental development (a review). J Reprod Immunol. 2002;57:151.

5. Christiansen OB, Nielsen HS, Kolte AM. Inflammation and miscarriage. Semin Fetal Neonatal Med. 2006;11:302-8.

6. Kusumawardani B, Soesatyo MHNE, Dasuki D, Asmara W. Fetal growth restriction in Porphyromonas gingivalis-infected pregnant rats. Dentika Dent J. 2011;16:26-30.

7. Kusumawardani B, Soesatyo MHNE, Dasuki D, Asmara W. Maternal endotoxin-induced fetal growth restriction in rats: Fetal responses in Toll-like receptor. Dent J. 2012;43:144-9.

8. Kusumawardani B, Soesatyo MHNE, Dasuki D, Asmara W. Placental trophoblast responses to Porphyromonas gingivalis mediated by Toll-like receptor-2 and -4. J Dent Indones. 2013;20:32-8.

9. Medzhitov R, Janeway Jr CA. Decoding the patterns of self and nonself by the innate immune system. Science. 2002;296:298-300.

10. Haider S, Knöfler M. Human tumor necrosis factor: physiological and pathological roles in placenta and endometrium. Placenta. 2009;30:111-23.

11. Thaxton JE, Sharma S. Interleukin-10: a multifaceted agent of pregnancy. American J Reprod Immunol. 2010;63:482-91.

12. Taylor A, Verhagen J, Blaser K, Akdis M, Akdis CA. Mechanisms of immune suppression by interleukin-10 and transforming growth factor- $\beta$ : the role of T regulatory cells. Immunol. 2006;117:433-42.

13. Akdis CA, Blaser K. Mechanisms of interleukin10-mediated immune suppression. Immunol. 2001;103:131-6.
14. Denney JM, Nelson EL, Wadhwa PD, et al. Longitudinal modulation of immune system cytokine profile during pregnancy. Cytokine. 2011;53:170-7.

15. Kanellopoulos-Langevin C, Caucheteux SM, Verbeke P, Ojcius DM. Tolerance of the fetus by the maternal immune system: role of inflammatory mediators at the feto-maternal interface. Reprod Biol Endocrinol. 2003;1:1-6.

16. Adamson SL, Lu Y, Whiteley KJ, Holmyard D, Hemberger $\mathrm{M}$, Pfarrer $\mathrm{C}$, et al. Interaction between trophoblast cells and the maternal and fetal circulation in the mouse placenta. Dev Biol. 2002; 250:358-73.

17. Georgiades P, Ferguson-Smith AC, Burton GJ. Comparative developmental anatomy of the murine and human definitive placentae. Placenta. 2002;23:3-19.

18. Martin RD. Human reproduction: a comparative background for medical hypotheses. J Reprod Immunol. 2003;59:111-35.

19. Hunt JS, Chen HL, Miller L. Tumor necrosis factors: pivotal components of pregnancy? Biol Reprod. 1996;54:554-62.

20. Moore KW, de Waal Malefyt R, Coffman RL, O'Gara A. Interleukin-10 and the interleukin-10 receptor. Annu Rev Immunol. 2001;19:683-765.

21. Lin D, Smith MA, Elter J, Champagne C, Downey CL, Beck J, Offenbacher S. Porphyromonas gingivalis infection in pregnant mice is associated with placental dissemination, increase in the placental dissemination, an increase in the placental Th1/Th2 cytokine ratio, and fetal growth restriction. Infect Immun. 2003;71:5163-8.

22. Trautman MS, Collmer D, Edwin SS, White W, Mitchell MD, Dudley DJ. Expression of interleukin-10 in human gestational tissues. J Soc Gynecol Investig. 1997;4:247-53.

23. Mosmann TR, Coffman RL. Heterogeneity of cytokine secretion patterns and functions of helper $\mathrm{T}$ cells. Advance Immunol. 1989;46:111-47.

24. Argawal R, Loganath A, Roy AC, Wong YC, Ng SC. Effect of T helper 1 cytokines on secretion of T helper 2 cytokines by term trophoblast cell in culture. Gynecol Endocrinol. 2000;14:305-10. 